\title{
Surface modification of calcium carbonate nanoparticles as hydraulic oil additives friction performance research
}

\author{
Yuan-sheng Ding, Hou Baoquan, Xv Zhai, Fei Lu \\ Department of Chemical and Pharmaceutical Engineering, \\ Jilin Institute of Chemical Technology, Jilin 132022, China
}

Received March 28, 2018

\begin{abstract}
In this experiment, calcium carbonate nanopartilces were prepared by metathesis method. The calcium carbonate powders were modified by sodium dodecyl sulfonate. The characteristics of raw and modified calcium carbonate powders were analyzed and characterized by various methods. The size of the unmodified nano-calcium carbonate is about $2.7 \mu \mathrm{m}$, and the particle size of the modified particles is about several hundred nanometers. The CFT-1 material performance tester was utilized to evaluate the tribological characteristics of the additive. The data show that the modified nano-calcium carbonate can improve the anti-friction and anti-friction performance of hydraulic oil.
\end{abstract}

Keywords: nanometer calcium carbonate, anti-wear and anti-friction.

\begin{abstract}
Наночастицы карбоната кальция были получены методом метатезиса. Порошки карбоната кальция модифицировали додецилсульфонатом натрия. Характеристики исходных и модифицированных порошков карбоната кальция были проанализированы различными способами. Размер наночастиц немодифицированного карбоната кальция составляет около 2,7 мкм, а размер модифицированных частиц составляет около нескольких сотен нанометров. Тестер материала СFT-1 использовался для оценки трибологических характеристик добавки. Данные показывают, что модифицированный карбонат наночастиц кальция может улучшить антифрикционные характеристики гидравлического масла.
\end{abstract}

Поверхнева модифікація наночастинок карбонату кальцію як дослідження ефективності тертя гідравличних присадок. Yuan-sheng Ding, Hou Baoquan, Xv Zhai, Fei Lu.

Наночастинки карбонату кальцію отримано методом метатезісу. Порошки карбонату кальцію модифікують додецилсульфонатом натрію. Характеристики сирих i модифікованих порошків карбонату кальція проаналізовано та охарактеризовано різними способами. Розмір немодифікованого карбонату нанокальцію складає біля 2,7 мкм, а розмір модифікованих частинок - біля декількох сотен нанометрів. Тестер характеристик матеріалу CFT-1 використано для оцінки трибологічних характеристик добавки. Показано, що модифікований карбонат нанокальцію може поліпшити антифрикційні властивості і антифрикаційні характеристики гідравлічного масла.

\section{Introduction}

$\mathrm{CaCO}_{3}$ is an inexpensive inorganic filler, which has been used more than one hundred years. Since low cost, non-toxic, without excitant and high whiteness, $\mathrm{CaCO}_{3}$ consequently get extensive application in rubber, paper, paint, printing ink, printing, cable, food, medicine, cosmetics, toothpaste, feed, oil and other industry filedes [1,2].

With the continuous research of nanometer materials, the research of calcium carbonate nanopartilces has become a hot spot in the calcium carbonate industry. However, 
compared with the ordinary $\mathrm{CaCO}_{3}$ powders, nano $\mathrm{CaCO}_{3}$ powders can not uniformly disperse in organic medium due to high surface energy and hydrophilicity. Therefore, it is necessary to modify nano $\mathrm{CaCO}_{3}$. Using the surfactant to modify of nanometer calcium carbonate lead to bring many advantages such as reducing the agglomeration force between particles, improve its dispersion in the matrix and the dispersion stability, reduce the interfacial tension of two phase [3].

The lubrication behavior of the lubricating oil is a complicated process. In the process of friction, due to adsorption in the contact surface, lubrication oil form a layer of liquid membrane, which cut off direct contact friction surface of micro convex body. Further more lubrication oil can effectively reduce the friction surface friction coefficient and wear rate. Due to changes in environmental factors (temperature, pressure, etc.), in the process of contact with a relative motion, complex physical chemistry makes the friction surface be difficult to maintain the bearing pressure, rough surface of micro convex body direct contact each other, which result in increasing the friction coefficient of friction surface, make the metal surface wear [4]. In order to improve the lubrication performance of lubricating oil and antiwear properties, we adopt calcium carbonate nanoparticles as lubricating oil additives, meanwhile antiwear and antifriction performance of system are analyzed .

\section{Experimental}

Anhydrous calcium chloride (analysis pure) was purchased from tianjin daimao chemical Co; Sodium dodecyl sulfonate; Anhydrous sodium carbonate (analysis pure) were from TianJin chemical reagent Co.

$60 \mathrm{mM} \mathrm{Na} \mathrm{CO}_{3}$ is mixed with $60 \mathrm{mM}$ $\mathrm{CaCl}_{2}$ in the same volume for 15 minutes. Sediment were obtained from the solution by centrifugation, and then cleaned with ethanol and deionized water several times, after that at $60{ }^{\circ} \mathrm{C}$ dried.

An anionic surfactant (sodium dodecyl sulfonate) was chosen as compound modifier for calcium carbonate by wet-modification method. A certain quality of nanometer calcium carbonate was mixed with different quality of the surface modification agent sodium dodecyl sulfonate (SDS) under the condition of $220 \mathrm{r} / \mathrm{min}$ heated to $80{ }^{\circ} \mathrm{C}$ for $4 \mathrm{~h}$, then the modified nanometer calcium carbonate products were obtained after filtered, washed and dried.

The obtained powders were characterized by scanning electron microscope (SEM), Fourier transform infrared (FTIR) spectroscopy. The particle size and distribution were determined by laser particle size distribution analyze. The contact Angle measurement instrument (JC2000D) was used to measure water contact Angle and evaluate the degree of hydrophobicity of nanometer calcium carbonate before and after modification.

The calcium carbonate nanoparticles were added to the base oil and then placed in the KQ5200DE ultrasonic oscillator for 10-20 min ultrasonic oscillation to make the nanometer calcium carbonate particles fully dispersed.

Reciprocating friction test were investigated by CFT-1 type material surface performance tester. The test sample is 45 \# steel steel disc with $30 \mathrm{~mm}$ in diameter, 5 $\mathrm{mm}$, hardness is $210 \mathrm{HB}$. Before test, steel block was ultrasonic washed with acetone for $15 \mathrm{~min}$ and blow dried. In the friction test machine, the reciprocating friction tests were carried out.

The friction rate of the test was $41.7 \mathrm{~mm} / \mathrm{s}$, the reciprocating length was $5 \mathrm{~mm}$, the motor speed was $500 \mathrm{r}$, and the friction loads were selected $60,90,120 \mathrm{~N}$, and the friction time was $40 \mathrm{~min}$. The friction coefficient was measured by the sensor in the test. The above test results are three times averaged.

\section{Results and discussion}

The contact of the modified nanometer calcium carbonate particles with different mass fraction of sodium dodecyl sulfonate were measured with JC2000D1 as shown in the Fig.1.

It can be seen that as the concentration of modifier increases, the contact angle increase which meaning $\mathrm{CaCO}_{3}$ surface become hydrophobicity after modified by SDS.

It can be seen from Table, the surfactant concentration has a great influence on particle size distribution of nanoparticles, optimum dosage was $3 \%$. The relevant literature also shows that the amount of surfactant has an optimal dosage for the dispersibility of nanoparticles in the lubricating oil, so our experiment use $3 \%$ SDS to modify $\mathrm{CaCO}_{3}$ in the followed section.

Nano $\mathrm{CaCO}_{3}$ and $\mathrm{SDS}_{-} \mathrm{CaCO}_{3}$ infrared spectra are shown in Fig.2. As can be seen from spectra of SDS- $\mathrm{CaCO}_{3}$, the absorption peak appeared at 2916, $2854 \mathrm{~cm}^{-1}$ which 
Yuan-sheng Ding et al. / Surface modification of ...

Table. Particle size analysis of nanometer calcium carbonate with different commodification

\begin{tabular}{||c|c|c|c|c|c||}
\hline $0 \%$ & $0.1 \%$ & $0.5 \%$ & $1 \%$ & $1.5 \%$ & $2 \%$ \\
\hline $2730 \mathrm{~nm}$ & $1657 \mathrm{~nm}$ & $944 \mathrm{~nm}$ & $800.4 \mathrm{~nm}$ & $600.3 \mathrm{~nm}$ & $400.1 \mathrm{~nm}$ \\
$2.5 \%$ & $3 \%$ & $3.5 \%$ & $4 \%$ & $4.5 \%$ & $5 \%$ \\
$350.6 \mathrm{~nm}$ & $210.5 \mathrm{~nm}$ & $475.7 \mathrm{~nm}$ & $694.5 \mathrm{~nm}$ & $1216 \mathrm{~nm}$ & $1280 \mathrm{~nm}$ \\
\hline
\end{tabular}

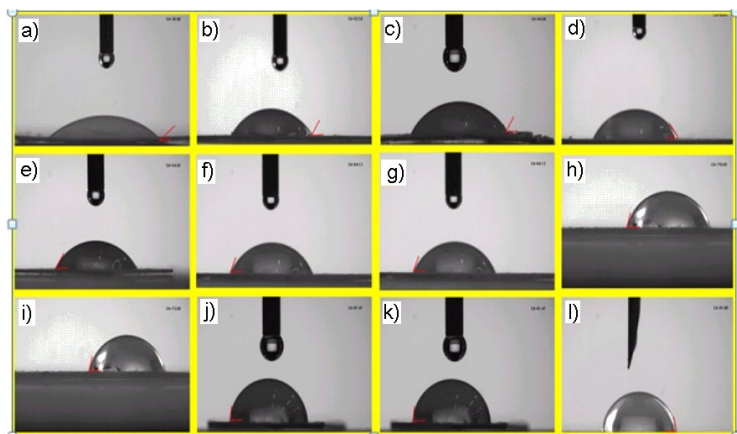

Fig. 1 Contact angle of nanometer calcium carbonate modified with different concentration of SDS: a, b, c, d, e, f, g, h, i, j, k, l respectively stand for $0 \%, 1 \%, 1.5 \%, 2 \%$, $3 \%, 3.5 \%, 4 \%, 5 \%, 6 \%, 7 \%$ sodium dodecyl sulfonate mass fraction.

are ascribed to the asymmetric and symmetric vibration of $\mathrm{CH}_{2}$. It concluded that $\mathrm{CaCO}_{3}$ were successfully modified by SDS from the above results [4].

As can be seen from Fig.3(a), the nanoparticle $\mathrm{CaCO}_{3}$ particles are irregular particles, and there is a certain degree of reunion with the particle size of 1-2 $\mu \mathrm{m}$; SEM experiment displays that the SDS $\mathrm{CaCO}_{3}$ has amorphology of granular structure with $200 \mathrm{~nm}$ even grain size. The SDS$\mathrm{CaCO}_{3}$ are monodisperse nanoparticles due to the alkyl chain of SDS inhibits the aggregation of $\mathrm{CaCO}_{3}$ particles

The friction coefficient variation of the lubricating oil with different concentration of modified $\mathrm{CaCO}_{3}$ particles are shown in the Table 2 below.

Under the load is $60 \mathrm{~N}$, pure hydraulic oil lubrication of the friction coefficient is 0.1128 . When the modified $\mathrm{CaCO}_{3}$ particles mass fraction is of $1 \%$, the friction coefficient is 0.0929 , compared with the pure hydraulic oil lubrication, friction coefficient decrease $17.65 \%$. When the mass fraction of modified $\mathrm{CaCO}_{3}$ particle in the hydraulic oil is $3 \%, 5 \%, 6 \%, 7 \%$, compared with the pure hydraulic oil lubrication friction coefficient respectively are reduced by $17.65 \%$, $20.22 \%, 11.27 \%, 19.77 \%, 11.27 \%$.

Under the load is $90 \mathrm{~N}$, the pure hydraulic oil lubrication of the friction coefficient

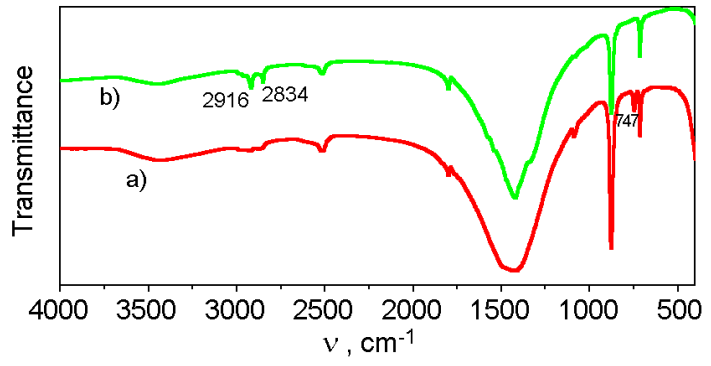

Fig.2. Infrared spectra before (a) and after (b) modification of nanometer calcium carbonate

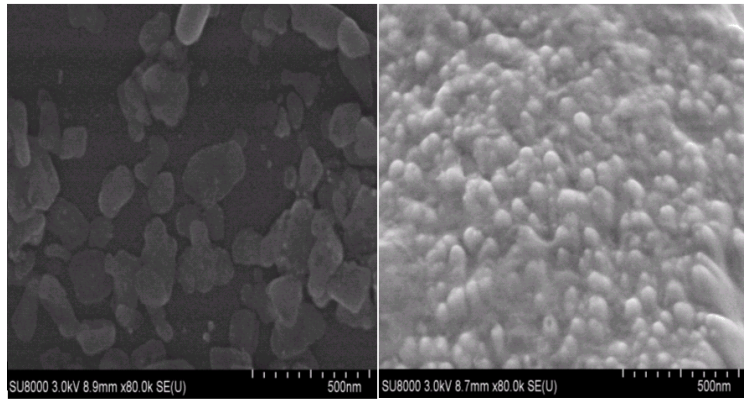

a)

b)

Fig.3. SEM of nanometer calcium carbonate unmodified and modified with of $3 \%$ SDS

is 0.0937 , when the mass fraction are of $1 \%, 3 \%, 5 \%$, the friction coefficient are $0.0917,0.0859,0.0885$, compared with the pure reduced friction coefficient when the hydraulic oil lubrication, was reduced by $2.09 \%, 8.29 \%$ and $2.09 \%$, respectively. When the mass fraction of calcium carbonate in the hydraulic oil was $6 \%$ and $7 \%$, the friction coefficient was 0.0941 and 0.968 respectively, and the friction coefficient increased by $0.44 \%$ and $13.75 \%$ respectively, compared with the pure hydraulic oil lubrication.

Under the load is $120 \mathrm{~N}$, the friction coefficient firstly decreased when the modified $\mathrm{CaCO}_{3}$ particles mass fraction is from $1 \%$ to $5 \%$, after that increase with the SDS- $\mathrm{CaCO}_{3}$ particles mass fraction.

From the above data, it is found that when the load is $90 \mathrm{~N}$, the data has a small fluctuation. When the load is $60 \mathrm{~N}$ and 120 
Table 2 Friction coefficient summary under different loads.

\begin{tabular}{|c|c|c|c||}
\hline \hline & $60 \mathrm{~N}$ & $90 \mathrm{~N}$ & $120 \mathrm{~N}$ \\
\hline Base oil & 0.1128 & 0.0937 & 0.0989 \\
$1 \%$ & 0.0929 & 0.0917 & 0.0931 \\
$3 \%$ & 0.09 & 0.0859 & 0.0919 \\
$5 \%$ & 0.1001 & 0.0885 & 0.0866 \\
$6 \%$ & 0.0905 & 0.0941 & 0.0959 \\
$7 \%$ & 0.0988 & 0.1066 & 0.0968 \\
\hline
\end{tabular}

$\mathrm{N}$ load, the overall data is gentle and lower than that of pure hydraulic oil. Thus it can be seen in the pure hydraulic oil to add a certain percentage of the SDS- $\mathrm{CaCO}_{3}$ can improve anti-friction effect, just under the different load, different amount of calcium carbonate is added the effect is different. When the quality fraction of modifier is $1 \%$, the friction coefficient under different loads is similiar.

\section{Conclusions}

As the surface modifier, SDS was successfully modified on the surface of nanometer $\mathrm{CaCO}_{3}$ by ultrasonic reaction. The experiment results showed that the optimum content of the SDS is $3 \%$. The surface is converted from hydrophilic to hydro- phobic, and the particles are not reunited with particle diameter is about $200 \mathrm{~nm}$.

The excellent lubricating effect of the antimony nanoparticles in the lubricating oil is observed because these nanoparticles fill in some micro-pits on the worn surface. With appropriate proportion, $\mathrm{SDS}-\mathrm{CaCO}_{3}$ can concertedly function as properties of anti-wear and friction reduction. In the present research, the best proportion of SDS$\mathrm{CaCO}_{3}$ is $3 \%$ under the $60 \mathrm{~N}$ load, the best proportion of $\mathrm{SDS}^{-\mathrm{CaCO}_{3}}$ is $5 \%$ under the 90N /120 N load.

\section{Acknowledgements}

The authors are grateful for the financial support provided by the Jilin Education Department Science Foundation of China (NO.2013320), Undergraduate innovation and entrepreneurship training program of China (201610192005) and Science and technology innovation and development project of JiLin City (201750253).

\section{References}

1. Qiao H. B., Guo Q., Mater. Mech. Eng., 29, 4, 2005.

2. Huang J., Li X., Zhang Z., Adv. Tribol., $890,2009$.

3. Sun X. F., Qiao Y. L., Song W., Ma S.N., Hu C.H., Phys. Procedia, 50, 343, 2013.

4. Yang Y., Ma J., Qi X.-Meng X., Wear, 318, 202, (2014). 